\title{
Postintubation tracheal stenosis - a rare cause of dyspnea
}

\author{
Stenoza de trahee postintubațională - o cauză rară de dispnee
}

\author{
Irina Cuciureanu ${ }^{1,2}$, Ioana Băjenaru ${ }^{2}$, Anamaria-Georgiana Avram ${ }^{1,2}$, Ion Alexandru ${ }^{1,2}$, \\ Cătălina Liliana Andrei ${ }^{1,2}$, Crina-Julieta Sinescu ${ }^{1,2}$ \\ ${ }^{1}$ Universitatea de Medicină și Farmacie „Carol Davila“, București, România \\ ${ }^{2}$ Clinica de Cardiologie, Spitalul Clinic de Urgență „Bagdasar-Arseni“, București, România
}

\begin{abstract}
Tracheal stenosis is a rare complication of tracheal intubation, which usually becomes symptomatic after some time after detubation, with typical superior airway obstruction signs and symptoms. This is a case of a 62 -yearold female with post intubation tracheal stenosis, with interesting problems of differential diagnosis until the final diagnostic was found. Clinical and imagistic investigations led us to our final diagnosis of iatrogenic post intubation tracheal stenosis.
\end{abstract}

Keywords: tracheal stenosis, differential diagnosis, dyspnea

\section{REZUMAT}

Stenoza traheală este o complicație rară a intubației orotraheale ce se manifestă de obicei la distanță de la extragerea sondei de intubație, prin simptome și semne tipice obstrucției de căi aeriene superioare. Áceastă patologie trebuie activ căutată la pacienții cu istoric de intubație orotraheală. Vă prezentăm cazul unei paciente în vârstă de 62 ani cu stenoză traheală postintubațională, care a pus probleme interesante de diagnostic diferențial până la elucidarea cazului. Investigațiile clinice și paraclinice efectuate au condus la diagnosticul final de stenoză traheală iatrogenă postintubație.

Cuvinte cheie: stenoză traheală, diagnostic diferențial, dispnee

\section{INTRODUCERE}

Stenoza traheală este o complicaţie tardivă și rară a intubației orotraheale prelungite, care poate deveni amenințătoare de viață. Incidența acesteia nu este bine stabilită, neexistând suficiente date la acest moment, însă un studiu publicat în 2007 menționa o incidență de 1-11\% (1), iar un altul din Marea Britanie realizat pe o populație de 2,72 milioane de oameni a estimat incidența stenozei traheale postintubație la 4,9\% pe an (2). Vă prezentăm cazul unei paciente cu stenoză traheală iatrogenă postintubaţie orotraheală prelungită, care a devenit simptomatică la două luni de la intubarea orotraheală.

\section{PREZENTAREA CAZULUI}

Pacientă în vârstă de 62 ani, cunoscută cu diabet zaharat tip 2 insulinonecesitant de 12 ani, se prezintă la camera de gardă pentru durere toracică anterioară difuză şi dispnee de repaus, simptomatologie debutată cu o zi anterior examinării. Din antecedentele personale ale pacientei, reținem: istoric recent (cu două luni anterior) de infarct miocardic cu supradenivelare de segment ST în teritoriul inferior trombolizat, complicat $\mathrm{cu}$ bloc atrioventricular complet tranzitor, cu necesar de cardiostimulare temporară și stop cardio-respirator cu necesar de intubație orotraheală prelungită (10 zile), leziuni tricoronariene (angioplastie per pri- 
mam cu stent farmacologic activ pe artera coronară dreaptă în segmentul I-II și leziuni restante: stenoză $70 \%$ pe artera descendentă anterioară în segmentul mediu, și stenoză $70 \%$ pe artera circumflexă în porțiunea medio-proximală), și disfuncție sistolică moderată de ventricul stâng (VS). La examenul clinic, identificăm o pacientă supraponderală (IMC de $27,34 \mathrm{~kg} / \mathrm{m}^{2}$ ), cu dispnee de repaus, saturația în oxigen $90 \%$ cu oxigenoterapie pe masca facială cu 6 1/min, fără raluri pulmonare, fără sufluri cardiace audibile, fără frecătură pericardică, fără galop, fără semne de congestie sistemică, în rest fără modificări patologice. Electrocardiograma arată un ritm sinusal, 70 bătăi pe minut, unda Q și $T$ negativ în derivațiile inferioare, aspect staționar pe parcursul internării. Biologic, remarcăm valorile NTproBNP și D-dimeri crescute, fără creșterea în dinamică a markerilor de necroză miocardică (mioglobină, troponină, CK/CKMB), hemogramă în limite normale, fără alte modificări patologice. Ecografia cardiacă arată ventricul stâng nedilatat, cu hipokinezie perete inferior şi lateral, disfuncție sistolică moderată de VS, FEVS $40 \%$, regurgitare mitrală moderată ischemică, regurgitare tricuspidiană severă, cavităţi drepte nedilatate și hipertensiune pulmonară ușoară.

Luând în considerare debutul brusc al simptomatologiei, creșterea D-dimerilor și antecedentele recente de imobilizarea prelungită la pat a pacientei, se completează investigațiile cu tomografie computerizată de torace cu substanță de contrast, care relevă trombi neocluzivi la nivelul arterelor principale pulmonare.

Astfel, la internarea pacientei avem câteva diagnostice posibile. Un sindrom coronarian acut susținut de simptomatologia descrisă, la o pacientă cu factori de risc, cu un infarct miocardic acut recent cu angioplastie per primam şi leziuni coronariene restante (posibil tromboză precoce intrastent sau implicarea unor noi leziuni dintre cele restante). Lipsa modificărilor pe EKG, markeri de necroză miocardică recoltați în dinamică în limite normale și lipsa tulburărilor de noi de cinetică la ecografia cardiacă sunt argumente împotriva diagnosticului de sindrom coronarian acut (SCA) - infarct miocardic acut fără supradenivelare de segment ST, rămânând posibilitatea unei angine instabile. Simptomatologia poate fi explicată și prin acutizarea unei insuficiențe cardiace (IC) la o pacientă cu cardiopatie ischemică cu disfuncție sistolică moderată de VS și NT proBNP crescut. Putem lua în considerare ca factor precipitant al IC un SCA - angina instabilă. Se exclud o anemie, o intercurență respiratorie, o tulburare de ritm sau conducere sau un proces infecțios ca factori ai decompensării insuficienței cardiace. Un al treilea diagnostic ce poate explica simptomatologia este trombembolism pulmonar cu risc intermediar scăzut (fără disfuncție ecografică a ventriculului drept, fără creșterea troponinei înalt sensibile, fără criterii de şoc). Pe de altă parte, putem considera că trombii vizualizați s-au dezvoltat în perioada în care pacienta a fost imobilizată la pat și pot să nu fie neapărat implicați în declanșarea simptomatologiei.

$\mathrm{Ca}$ atitudine terapeutică, se inițiază tratament anticoagulant cu heparină cu greutate moleculară mică în doză terapeutică și se continuă tratamentul bolii cardiace ischemice și al disfuncției sistolice de VS. Sub acest tratament, evoluția pacientei a fost staționară, fără o îmbunătătire clinică evidentă, cu persistența dispneei de repaus. Ulterior, pacienta dezvoltă disfonie și stridor, semne tipice unei obstrucții de căi respiratorii superioare și, având în vedere că pacienta are istoric recent de intubaţie orotraheală, se ridică suspiciunea unei complicații tardive a manevrei invazive, și anume stenoză laringo-traheală. Se solicită consult ORL cu efectuarea laringoscopiei, care nu identifică elemente patologice la acest nivel. Se continuă bilanțul cu efectuarea unei tomografii computerizate a regiunii gâtului, care relevă o reducere a calibrului traheei de la $15 \mathrm{~mm}$ la $9 \mathrm{~mm}$, pe o lungime de $2 \mathrm{~cm}$. În aceste condiții, se solicită consult de chirurgie toracică cu efectuarea bronhoscopiei, care pune în evidență o stenoză circumferențială ,în diafragm“ la nivelul treimii medii a traheei. La acel moment, se consideră că pacienta nu are indicație de intervenție chirurgicală și se inițiază tratament antiinflamator steroidian sistemic, sub care evoluţia clinică a pacientei este favorabilă, cu remiterea simptomatologiei și evoluție locală la nivel traheal bună. Ulterior, pacienta a fost reevaluată într-o clinică de chirurgie toracică, unde i s-au efectuat dilatări endobronșice succesive, cu evoluție favorabilă.

\section{DISCUŢII}

Intubația orotraheală este o manevră invazivă menită să mențină permeabilitatea căilor aeriene superioare și, astfel, asigurarea unei oxigenări adecvate în timpul intervențiilor chirurgicale sau în cazul insuficienței respiratorii acute. Este o manevră din ce în ce mai des utilizată, încă din timpul celui de-al doilea război mondial, dar este însoțită de o serie de complicații locale, cum ar fi edem, ulcerații, pseudomembrane sau țesut de granulație 
la nivelul laringelui sau traheei sau mobilitate anormală a corzilor vocale (3-5). În trecut, se utilizau sonde de intubaţie cu balon cu volum și presiune mari care predispuneau la complicații postprocedurale. Medicul Hermes C. Grillo a fost cel care a demonstrat beneficiile utilizării unei sonde traheale cu balon cu volum mare și presiune mică în detrimentul celor cu volum și presiuni crescute în prevenția stenozei traheale (6). Astfel, incidența acestei complicații a scăzut pe parcursul anilor, însă rămâne o patologie cu morbiditate importantă și, în unele cazuri, poate fi fatală. Până în acest moment, incidența exactă a acestei complicații nu a fost determinată.

Fiziopatologic, presiunea balonului aplicată pe mucoasa traheală poate induce ischemie la acest nivel dacă aceasta depășește presiunea capilarelor (7). Dacă această presiune este menținută pe o durată mai lungă, se poate transforma în necroză. Ulterior, după înlăturarea tubului, începe procesul de cicatrizare care se poate întinde pe o durată de 3 până la 6 săptămâni $(6,7)$, explicând debutul tardiv și progresiv al simptomelor specifice obstrucției de căi aeriene superioare, exact ca în cazul pacientei noastre. Pentru a preveni acest proces, în prezent se recomandă monitorizarea zilnică a presiunii din balonul sondei de intubație și menținerea acesteia la valori mai mici de $30 \mathrm{mmHg}(6,7)$. Rolul balonului nu este numai de a fixa sonda de intubație, ci și de a preveni refluxul sucurilor gastrice în căile aeriene care pot genera leziuni $(7,8)$. Pe parcursul timpului, s-au publicat articole și studii care au încercat să identifice o serie de factori de risc care predispun la dezvoltarea stenozei traheale postintubație. Un astfel de studiu publicat în 2007 a identificat intubația prelungită peste 48 de ore ca factor predispozant pentru stenoze laringotraheale (1).

Clinic, simptomatologia stenozei traheale postintubaționale nu diferă de cea a obstrucției de căi aeriene superioare, și anume se manifestă prin wheezing, stridor și dispnee. Aceasta devine evi-

\section{Conflict of interest: none declared}

Financial support: none declared

\section{BIBLIOGRAFIE}

1. Koshkareva Y, Gaughan JP, Soliman AM. Risk factors for adult laryngotracheal stenosis: a review of 74 cases. Ann Otol Rhinol Laryngol. 2007 Mar;116(3):206-10.

2. Nouraei SA, Ma E, Patel A, Howard DJ, Sandhu GS. Estimating the population incidence of adult post-intubation laryngotracheal stenosis. Clin Otolaryngol. 2007 Oct;32(5):411-2.

3. Deeb ZE, Williams JB, Campbell TE. Early diagnosis and treatment of laryngeal injuries from prolonged intubation in adults. Otolaryngol Head Neck Surg. 1999 Jan;120(1):25-9.

4. Lins M, Dobbeleir I, Germonpré P, Waelput W, Pauwels P, Jorens PG. Postextubation obstructive pseudomembranes: a case series dentă atunci când apare o reducere a diametrului traheal de 75\% (7). Însă aceste semne și simptome se instalează lent, uneori pretând la confuzie cu debutul unui astm bronșic. Conform lui Hermes C. Grillo, în cazul oricărui pacient care dezvoltă simptome de obstrucție de căi aeriene, cu istoric recent de intubație și ventilație mecanică, trebuie luată în considerat o leziune organică până la proba contrarie (6). Pentru evidenţierea și localizarea leziunii, se folosesc metode imagistice precum radiografia toracică, tomografia computerizată sau imagistica prin rezonanță magnetică $(9,10)$. Bronhoscopia este o metodă invazivă care permite vizualizarea directă și caracterizarea leziunii organice laringo-traheale, dar și tratamentul endoscopic al acesteia (11).

Particularitatea cazului prezentat constă în asocierea a trei diagnostice care puteau să justifice simptomatologia la o pacientă care s-a prezentat în urgență pentru dispnee. Un sindrom coronarian acut - angina instabilă, insuficiență cardiacă acutizată și trombembolismul pulmonar, la o pacientă cu antecedente de infarct miocardic cu supradenivelare de segment ST recent complicat cu stop cardio-respirator, cu necesar de intubație orotraheală prelungită și imobilizare la pat (10 zile), cu leziuni tricoronariene parțial rezolvate intervențional și disfuncție sistolică moderată de VS.

Surpriza cazului a fost că pacienta asocia o stenoză traheală postintubație orotraheală prelungită, cu evoluție clinică și locală foarte bună sub tratament medicamentos. Astfel, cel mai probabil, această stenoză traheală era patologia ce a determinat simptomatologia pacientei.

\section{CONCLUZII}

Stenoza traheală este o complicație tardivă rară și gravă, dar care trebuie luată în considerare și obiectivată la pacienții care au istoric recent de intubație orotraheală, aceasta având morbiditate crescută. and review of a rare complication after endotracheal intubation. Lung. $2011 \mathrm{Feb} ; 189(1): 81-6$.

5. Tadié JM, Behm E, Lecuyer L, Benhmamed R, Hans S, Brasnu D, Diehl JL, Fagon JY, Guérot E. Post-intubation laryngeal injuries and extubation failure: a fiberoptic endoscopic study. Intensive Care Med. 2010 Jun;36(6):991-8.

6. Wain JC. Postintubation tracheal stenosis. Chest Surg Clin N Am. 2003 May;13(2):231-46.

7. Shenoy L, Nileshwar A. Postintubation Tracheal Stenosis: A Devastating Complication! Indian J Respir Care. 2019 JulyDecember; 8(2):69-70. 
8. Cooper JD. Tracheal Injuries Complicating Prolonged Intubation and Tracheostomy. Thorac Surg Clin. 2018 May;28(2):139-144.

9. Wright CD, Li S, Geller AD, Lanuti M, Gaissert HA, Muniappan A, Ott HC, Mathisen DJ. Postintubation Tracheal Stenosis: Management and Results 1993 to 2017. Ann Thorac Surg. 2019 Nov; 108(5):1471-1477.

10. Taha MS, Mostafa BE, Fahmy M, Ghaffar MK, Ghany EA. Spiral CT virtual bronchoscopy with multiplanar reformatting in the evaluation of post-intubation tracheal stenosis: comparison between endoscopic, radiological and surgical findings. Eur Arch Otorhinolaryngol. 2009 Jun;266(6):863-6.

11. Shadmehr MB, Abbasidezfouli A, Farzanegan R, Pejhan $S$, Daneshvar Kakhaki A, Sheikhy K, Saghebi SR, Sadeghbeigee F, Gharedaghi A, Jahanshahi N, Zangi M. The Role of Systemic Steroids in Postintubation Tracheal Stenosis: A Randomized Clinical Trial. Ann Thorac Surg. 2017 Jan;103(1):246-253. 